\title{
PLANKTON DIATOMS OF THE "TOKO-MARU" VOYAGE (BRAZIL COAST)
}

\author{
F. C. Müller-Melchers *
}

The Japanese fisheries research vessel, that visited the coast of Brazil collected besides other materials a set of plankton gatherings that were deposited in the Instituto Oceanográfico at São Paulo.

Mr. J. de Paiva Carvalho had the kindness to place a number of these gatherings of plankton at my disposal to be analvsed according to their contents in diatoms. My very best thanks to Mr. J. de Paiva Carvalho for his kindness.

The gatherings consist of two groups: 4 samples from the south and the rest, 14 samples from around the mouth of the Amazonas River, below and above the equator. The two groups are very distinct from one and another, the 4 samples from the South have a very marked tendency to the Rio Grandense - Uruguayan marine province. The discoid forms of Actinocyclus and Coscinodiscus prevail in this material. These 4 samples from the south, to a certain extent are similar to the Uruguayan coast. This had already been noted in botton samples from Rio Grande do Sul (Barra). A large amount of Actinocyclus specimens were found. At first it seemed that these specimens might belong to Actinoc. tortuosus Mann. After further investigation I decided on a new species proposing the name of Actinocyclus brasiliensis. A fair number of Actinocyclus octanarius Ehbg., as well as Actinocyclus platensis MM., were found. The same diatoms were found in bottom samples taken by Mr. Plinio Soares Moreira from aboard the corvette "Solimões" (Brazilian navy). It seems that this marine province reaches from Uriguay $\left(39^{\circ}-28^{\circ}\right.$ South latitude) along the Brazilian coast. The Coscinodiscus forms are mostly the same as from the Uruguayan and Argentine coast. Coscinodiscus oculus iridis Ehbg., was found as the most frequent. There are small differences in areolation and form of the rosette that may have been produced by colder waters in the south. Coscinodiscus Kurzii Grunow

* This paper was prepared under auspecies of the Conselho Nacional de Pesquisas at Rio de Janeiro, which made possible the study of this material. I am greatly indebted to this Institution for letting me study at the Instituto Oceanográfico de São Paulo, my very best thanks. 
frequent at Cananéia (Estado de São Paulo) $25^{\circ}$ lat. S $48^{\circ} 55^{\prime} \mathrm{W}$ and described by me as Coscinodiscus heteroporus Enbg., in Las Diatomeas del Plancton Marino de las costas del Brasil on page 110, was found only twice, beeing brackish, it must have been washed out to sea by currents. I have given a detailed description of this diatom in this paper... The group of Actinoptychus is represented by three forms. Further investigation will show if types of Actinoptychus senarius (undulatus) Ehbg. that have been found and show certain differences in areolation belong to other or new species. The Chaetoceros group is relatively poor in these gatherings, or it may be that the samples at my disposal wehe rather exiguous. Chaetoceros Okamurai Ikari was found as new for the South American Coast. In Chaetoceros pseudocurvisetus Mangin, resting spores were found. Illustrations of these are not known to me and given in this paper. They are smooth like Chaetoceros curvisetus Cleve.

The Amazonas material is poor in forms and consists chiefly of Coscinodiscus concinnus W. Smith in great quantities, Coscinodiscus oculus iridis Ehbg., in less. They are accompanied by Nitzschia pungens var. atlantica Cleve, which I believe is found for the first time on the South American Coast. Cupp, West Coast of U. S. A., found this diatom at Lower and Southern California, and describes it as neritic temperate form. Gaarder only describes Nitzschia delicatissima Cleve with which Nitzschia pungens var. atlantica Cleve sometimes has been confused.

In "Toko-Maru" materials there is no doubt in my definition it shows well the striation that is difficult or not visible in $N$. delicatissima, also this latter is more slender. The other frequent diatom in the equatorial material is Ditylum Brightwellii Grunow that is found, nearly always with resting spores.

São Paulo - April/May 1957.

Atlantida. Uruguay. January 1958.

\section{STATIONS OF "TOKO-MARU" — 1957 - ALONG THE BRAZILIAN COAST.}

\begin{tabular}{|c|c|c|c|}
\hline \multirow[b]{2}{*}{ St. } & \multicolumn{2}{|c|}{ Position } & \multirow[b]{2}{*}{ Date } \\
\hline & Lat. & Long. & \\
\hline 133 & $0^{\circ} 34^{\prime} 00^{\prime \prime} \mathrm{N}$ & $47^{\circ} 39^{\prime} 00^{\prime \prime} \mathrm{W}$ & $19-4-957$ \\
\hline 135 & $0^{\circ} 54^{\prime} 05^{\prime \prime} \mathrm{N}$ & $47^{\circ} 18^{\prime} 07^{\prime \prime}$ W & $20-4-957$ \\
\hline 137 & $1^{\circ} 22^{\prime} 02^{\prime \prime} \mathrm{N}$ & $46^{\circ} 53^{\prime} 02^{\prime \prime} \mathrm{W}$ & $20-4-957$ \\
\hline 139 & $1^{\circ} 07^{\prime} 05^{\prime \prime} \mathrm{N}$ & $48^{\circ} 18^{\prime} 08^{\prime \prime} \mathrm{W}$ & $20-4-957$ \\
\hline 141 & $1^{\circ} 31^{\prime} 00^{\prime \prime} \mathrm{N}$ & $48^{\circ} 00^{\prime} 00^{\prime \prime} \mathrm{W}$ & $8-4-957$ \\
\hline 115 & $2^{\circ} 00^{\prime} 00^{\prime \prime} \mathrm{S}$ & $44^{\circ} 02^{\prime} 00^{\prime \prime}$ W & $6-4-957$ \\
\hline 117 & $0^{\circ} 23^{\prime} 00^{\prime \prime} \mathrm{S}$ & $46^{\circ} 55^{\prime} 00^{\prime \prime} \mathrm{W}$ & $10-4-957$ \\
\hline 125 & $0^{\circ} 44^{\prime} 00^{\prime \prime} \mathrm{S}$ & $45^{\circ} 45^{\prime} 00^{\prime \prime} \mathrm{W}$ & $8-4-957$ \\
\hline 123 & $0^{\circ} 36^{\prime} 05^{\prime \prime} \mathrm{N}$ & $44^{\circ} 23^{\prime} 00^{\prime \prime} \mathrm{WV}$ & $8-4-957$ \\
\hline 13 & $0^{\circ} 34^{\prime} 05^{\prime \prime} \mathrm{N}$ & $46^{\circ} 31^{\prime} 00^{\prime \prime} \mathrm{W}$ & $11-4-957$ \\
\hline
\end{tabular}




\begin{tabular}{|c|c|c|c|}
\hline 140 & $1^{\circ} 19^{\prime} 02^{\prime \prime} \mathrm{N}$ & $48^{\circ} 09^{\prime} 05^{\prime \prime} \mathrm{W}$ & $21-4-957$ \\
\hline 145 & $2^{\circ} 39^{\prime} 00^{\prime \prime} \mathrm{N}$ & $46^{\circ} 58^{\prime} 00^{\prime \prime}$ & $21-4-957$ \\
\hline 159 & $4^{\circ} 51^{\prime} 05^{\prime \prime} \mathrm{N}$ & $50^{\circ} 07^{\prime} 05^{\prime \prime} \mathrm{W}$ & $24-4-957$ \\
\hline 161 & $4^{\circ} 31^{\prime} 00^{\prime \prime} \mathrm{N}$ & $50^{\circ} 35^{\prime} 02^{\prime \prime}$ W & $24-4-957$ \\
\hline 193 & $28^{\circ} 06^{\prime} 03^{\prime \prime} \mathrm{S}$ & $48^{\circ} 32^{\prime} 08^{\prime \prime} \mathrm{W}$ & $13-1-957$ \\
\hline 196 & $28^{\circ} 50^{\prime} 02^{\prime \prime} \mathrm{s}$ & $49^{\circ} 05^{\prime} 04^{\prime \prime} \mathrm{W}$ & $15-1-957$ \\
\hline 212 & $33^{\circ} 26^{\prime} 00^{\prime \prime} \mathrm{S}$ & $52^{\circ} 28^{\prime} 05^{\prime \prime} \mathrm{W}$ & $27-1-957$ \\
\hline 213 & $33^{\circ} 54^{\prime} 05^{\prime \prime} \mathrm{s}$ & $53^{\circ} 10^{\prime} 05^{\prime \prime} \mathrm{W}$ & 28-1-957 \\
\hline
\end{tabular}

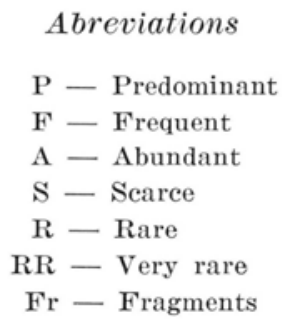

Actinocyclus brasiliensis n. sp. (Plate I, fig. 1a-1b) $0.086-0.090 \mathrm{~mm}$

Surface flat to the border, where it descends gently. Colour dark brown, purplish. Central space semicircular bearing a few closely packed granules. Markings granular 10 in $0.01 \mathrm{~mm}$. A few hyaline interspaces give a sunburst effect. The rays of granules are flexuose towards the border. Border striae indiscernable. Pseudonodule very small, $0.002 \mathrm{~mm} \varnothing$ (2) indistinct (obsolete).

$\mathrm{N}$. Ingram Hendey suggests (in litt.) that the specimens might be identified as Actinocyclus tortuosus Mann. (Austral. Antartic Exped. p. 21, pl. 1, fig. 9 and plate 2, fig. 1 .

It has as great resemblance but the hyaline interspace in A. tortuosus are of a very much greater number and more tortuous; the same applies to the granular rays. So the above name is given "ad interim".

Stat.: $193 \mathrm{RR}-196 \mathrm{R}-212.213$.

Actinocychs octanarius Ehrenberg, 1838. (Plate II, fig. 5). 1861 Actinocyclus Ehrenbergii Ralfs ex Pritchard.

Dr. N. Ingram Hendey in Discovery Rep., XVI, p. 259 has reinstated the name of Actinocyclus octanarius as type.

The iridescent colours will be very libht sky blue others of dark purple. The latter seem to belong to the type moniliformis. Rattray (p. 182) describes this as a separate species, but I believe it should be drawn together with $A$. octanarius as it is very closely identical. Eventually a variety.

Stat:. 212 and 213 - not common. 
Actinocyclus platensis Müller-Melchers, 1954.

This species seems to belong to southern Brazil, Uruguay and Argen. tine. It was not found around the mouth of the Amazonas River. Sтат.: 193, 212 and 213.

Actinoptychus areolatus Ehremberg, 1854. (Plate I, fig. 2, 3)

Microgr., 33, f. XIII, f. 17 .

Schmidt Atlas, table 1, fig. 9; table 29, fig. 4 .

Brockmann, Chr. Marin. Quartaer Hollands, p. 54.

Very rare. This species is distinguished by 6 spines, one in each sector, else very much like A. senarius Ehbg. The areole are smaller and more crowded.

Stat.: 212.

Actinoptychus campanulifer A. Schmidt, 1875.

One only specimen was found. Well known further to the north, on the coast of Estado de São Paulo.

Stat.: 193.

Actinoptychus turgidus T. \& Brun? (Plate I, fig. 4)

The following description is made from one specimen only, this was so delicate that most of the areolation could not be seen. A type very closely related to this was found around Cananéia at "Costa do Cardoso". I give the description as follows: $0.125 \mathrm{~mm} \varnothing$, of a very pale yellow colour; six sector, about all of the same hight. Each sector slightly curved. Hexagon hyaline space in the middle indistinct. Spines one or two could be made out? Granulation partly paralel or disorderly, $7 / 8$ in $0.01 \mathrm{~mm}$ valve about flat.

It might belong to Actinoptychus turgidus. The specimens from "Costa do Cardoso" seem to be related to this one. A. S. Atlas, 173, fig. 1. Stat.: 193.

Asteromphalus Hookerii Ehrenberg 1844. (Plate III, fig. 9)

Microgeolog., vol. XXXV, A 21, fig. 2.

Rattray, Rev. Coscinod. 9.656 (1889)

Karsten, Valdivia Antarktischen, p. 90, lam. VIII, fig. 9. (1905)

Mann, Albatross, p. 275 (1907)

Müller-Melchers, Diat. Planct. Mar. Brasil, p. 100, lam. I, fig. 1 (1955).

A rare species on the Brazilian coast. Oceanic, pelagic?

Stat.: 212.

Bacteriastrum delicatulum Cleve, 1897.

Rather rare.

SтAт.: 196 and 212. 
Bacteriastrum hyalinum Lauder, 1864.

Not common, some specimen showed resting spores.

Sтат.: 193, 196 and 212.

Biddulphia aurita (Lygbye) Brébisson et Godé், 1838.

Brébisson et Godey, Cons. sur. les Diat., p. 12. (1838).

Hustedt, Diatomeen der Nordesee Dollart bis Elbe. (1939). Biddulphia rostrata, p. 591, fig. 5-7.

Gaarder, M. Sars Exped., vol. II, n. ${ }^{\circ} 2$ (1951).

Biddulphia aurita var. minima $-0.02 \mathrm{~mm}$.

A very small variety of this species was found in only a few specimens. Size of our specimens $0.0174 \mathrm{~mm}$ width.

SтAт.: 115 and 131.

Biddulphia chinensis Gréville, 1866.

Quite a large amount was found at station 212 and 213. It might be an other endemic centre like the one on the Argentine coast in front of Samborombóo.

Width -0.188 to $0.202 \mathrm{~mm}$.

Stat.: $193,212 \mathrm{~F}$ and $213 \mathrm{~A}$.

Biddulphia laevis Ehrenberg, 1843.

Marine brackish form. Rio Grande do Sul, Cananéia (M.M.) Stat.: 193 and 212.

Biddulphia mobiliensi Bayley, 1845.

Together with Biddulphia chinensis but in much smaller amount. Not rare.

Stat.: 193, 196, 212 and 213.

Biddulphia regia (Schultze Ostenfeld, 1908.

Sтат.: 125, 131, 139 and 145.

Biddulphia rhombus Wm. Smith, 1851.

Stat.: 212 and 213.

Chaetoceros affinis Lauder, 1864.

Stat.: 212 and 213.

Chaetoceros coarctatus Lauder, 1864.

Stat.: 193 and 212Fr. 
Chaetoceros compressus Lauder, 1854.

Stat.: 193Fr.

Chaetoceros curvisetus Cleve, 1889.

Stat.: 213 Fr. (rare).

Chaetoceros didymus Ehremberg, 1846.

Stat.: 193 R.

Chaetoceros lorenzianus Grunow, 1863 (Plate IV, fig. 13). found.

Marine and brackish. Several resting spores of this species were Stat.: 193.

\section{Chaetoceros Okamurai Ikari, 1928 (Plate VI, fig. 21)}

Botan. Magazine Tokyo, vol. XLII, p. 248, fig. 2.

Chain straight, not twisted. Cells in front view broad, quadrangular with rounded angles, sometimes elongated. Valve convex and elevated to two low cones, leaving a shallow depression. Foramina rhomboidal. Setae start direct from these cones and each then coalesces with the other. Setae long and straight adorned with spines. Terminal setae not found.

LocaLity: seas of Japan, Ikari. Warm water type!

The material found was in fragmentary state. Cells of 0.030 width, 0.44 hight, with rhomboid foramina. Heavy setae, but these were all brocken not one was found in entire lenght. Most of the specimens were found two cells together.

Not found to the South of Brazil. New for Brazil and South America. Stat.: 115, 131, 159, and $161 \mathrm{Fr}$.

Chaetoceros peruvianus Brightwell, 1856.

Stat.: 193.

Chaetoceros pseudocurvisetus Mangin, 1910 (Plate III, fig. 11)

Tropical, subtropical, neritic.

Fairly common. Known from Cananéia surroundings.

In one chain resting spores were found. I believe that this is the first time that this has been noted in this species. Cupp (1943) does not mention resting spores.

Stat.: 212.

Chaetoceros rostratus Lauder, 1864.

Stat.: 212 and 213. 
Corethron pelagicus Brun., 1891 (Plate V, fig. 22).

Mém. Soc. Phys. Genève, vol. XXXI, 2, n. ${ }^{\circ} 1$, p. 20, plate XIX, fig. 6.

Hustedt, Kieselalgen, p. 547, fig. 312 A. B. (1930).

Hendey, South Seas, Discovery Rep., XVI, p. 329, "pelagicum phase" (1937).

"The chief difference between this and the other phases are considerable, shortning of connective zone and increased diameter of cell" (Hendey).

The material was mostly in bad state and fragmentary. I give several measurements from Uruguayan material that are coincident with Brazil specimens:

$$
\begin{aligned}
& 0.052 \text { hight } \mathrm{x} 0.065 \mathrm{~mm} \varnothing \\
& 0.063 \text { " } 0.020 \mathrm{~mm} \text { " } \\
& 0.090 " \quad \text { x } 0.020 \mathrm{~mm} \text { " } \\
& 0.090 \% \quad \text { x } 0.060 \mathrm{~mm} \text { ” } \\
& 0.100 " \quad \text { x } 0.081 \mathrm{~mm} \text { " } \\
& 0.151 \text { x } 0.060 \mathrm{~mm} \text { " }
\end{aligned}
$$

My citation in Las Diatomeas del Plancton Marino de las costas del Brasil (1955) p. 107, should be changed to Corethron pelagicum Brun.

Stat.: 193 and $212 \mathrm{~F}$.

Coscinodiscus asteromphalus Ehremberg, 1844.

Sтат.: 212 and 213.

Coscinodiscus commutatus Grunow, 1884.

Brackish marine indicator.

Stat.: 115, 125, 139, 140, 145, 193 and 212.

Coscinodiscus concinnus Wm. Smith, 1856.

Very common and sometimes predominant in the Amazonas region.

$$
\begin{array}{ccc}
\text { Cells about } 0.172 \varnothing & \text { upper cell } 0.0344 \text { high. } \\
\text { girdle } & 0.0559 \text { high. } \\
\text { lower cell } 0.0516 \text { high. }
\end{array}
$$

0.1419 about as high as diameter.

Valves all with closed middle center. The open center has not been found on the South America coast.

Stat.: 115, 125, 131, 139, 140, $141 \mathrm{P}, 145 \mathrm{~A}$, and 161.

Coscinodiscus divisus Grunow, 1878.

Stat.: 193 S.

Coscinodiscus excentricus Ehrenberg, 1839.

Stat.: 193, 212 and 213 (about $0.040 \mathrm{~mm}$ ). 
Coscinodiscus gigas var. praetextus (Janisch) Hustedt, 1928.

Stat.: 212 and 213.

Coscinodiscus Hustedtii Müller-Melchers, 1954.

Warm water indicator.

Stat.: 125, 131, 140 and 213.

Coscinodiscus Jonesianus Ostenfeld, 1915, var. aculeata Meister, 1932 (Plate II, fig. 6).

Meister Asien.

Lengh of spines about $0.0012 \mathrm{~mm}$ to $0.0014 \mathrm{~mm}$. About $0.172 \varnothing$ the spines are the only difference to the species.

On the Uruguayan coast in Coscinodiscus commutatus something like this variety is found but in this case the spines are more like apiculi. Sтат.: 131, 139.

\section{Coscinodiscus Kurzii Grunow ex Schmidt, 1888.}

Schmidt Atlas, plate 113, fig. 17, Elephant Point - Bengal, 1888.

Lohman, Pliocen Diatoms Kettleman Hills, Prof. Paper 189C, plate 20, fig. 1; plate 21, fig. 2, 1938 .

Both without rosette and closed centre.

Together with Hemidiscus ovalis Lohman and other marine brackish forms.

Lohman, Deepsea Cores, Prof. Paper 196B, p. 71. 13, fig. 5, 1941.

Müller-Melchers, Diat. Planct. Mar. Brasil, 1955, as Coscinodiscus heteroporus (at that time the author could not consult the A. Schmidt Atlas).

Kolbe, Swed, Deep. Sea Exped. Diatoms from Equat. Atlantic Cores, vol. VII, fasc. 3 , p. 169,1955 .

$$
\begin{aligned}
& \text { Core n. }{ }^{\circ} 22320^{\circ} 21^{\prime} \mathrm{N} \quad 20^{\circ} 37^{\prime} \mathrm{w} \\
& 2353^{\circ} 12^{\prime} \mathrm{N} \quad 20^{\circ} 38^{\prime} \mathrm{W} \\
& 238 \quad 0^{\circ} 07^{\prime} \mathrm{S} \quad 18^{\circ} 12^{\prime} \mathrm{W}
\end{aligned}
$$

I am not of Kolbe's opinion to unit Cos. Kurzii with Cos. obscurus they have both quite different areolation.

Hendey - in litteris - Plankton Sierra Leone. West Africa.

With closed centre.

As very little is known of this diatom and as this represents one of the most frequent Coscinodiscus at Cananéia, Estado de São Paulo, Brazil, I have examined more closely the various data at hand.

A. Schmidt Atlas, pl. 113, f. 17. Festooned border of small cells. Band of about 3 to 4 circles of larger areola diminishing later to to centre. Ring of small areola at the centre with small hyaline space of about $0.002 \mathrm{~mm}$. Coscinodiscus Kurzii Grunow, from Cananéia, Brazil (Plate II, fig. 8): 
about 0.084 to $0.165 \varnothing$, border of festoonated smaller areola, like garlands (festoons of a curtain) 6 in $0.01 \mathrm{~mm}$. Then follows a band of larger areola, 4 in $0.01 \mathrm{~mm}$ and after this the large areola about 3 to 4 circlets of $21 / 2$ in $0.01 \mathrm{~mm}$ to diminish to 3 in $0.01 \mathrm{~mm}$ till they reach the ring of small areola 4 in $0.01 \mathrm{~mm}$ leaving a hyaline centre space that measures about 0.003 to $0.004 \mathrm{~mm}$ and that in smaller specimens some times does not exist. Before the inserted rays small poroids are found (immersion!).

The Sierra Leone (Africa) built of the valves is very like those from Brazil and the drawings in A. S. A., p. 113, f. 17, only the small hyaline space in the middle is missing. But I do not imagine that this should alter the type, as in very small Brazil specimens it is very small.

Stat.: 213. Only very few specimens were found. It seems that Coscinodiscus Kurzii prefers warm brackish water. At Cananéia it was found in brackish to marine surroundings, it will support very low salinity. It was found out at sea in front of the Ilha da Boa Vista.

Coscinodiscus obscurus A. Schmidt, 1878.

$0.058-0.079 \mathrm{~mm} \varnothing$, about $31 / 2$ areola in $0.01 \mathrm{~mm}$ with small hyaline centre and poroids.

Stat.: 193 R.

Coscinodiscus oculus iridis Ehrenberg, 1839.

Frequent in most stations, found along most of the South Atlantic coast.

Stat.: 115, 137, 145, 161, 197, 212 and 213.

Coscinodiscus pacificus Grunow, 1884.

Stat.: 212 and 213.

Coscinodiscus perforatus Ehrenberg, 1844.

Stat.: 212 and 213.

Coscinodiscus punctiger (Castr.) Müller-Melchers, 1953.

Sтат.: 196, 212 and 213. Scarce and rare.

Coscinodiscus radiatus Ehrenberg, 1839.

Stat.: 115, 145, 161, 193, 212 and 213.

Coscinodiscus Rothii (Ehr.) Grunow, 1878.

Stat.: 212 and 213. Rare.

Coscinodiscus Vidovichii Müller-Melchers, 1953.

Stat.: 212 R. 
Cyclotella striata var. ambigua Grunow, 1882.

Frenguelli, San Blas, p. 331, 1938.

Brackish water indicator $-0.024 \mathrm{~mm} \varnothing, 11$ stria in $0.01 \mathrm{~mm}$. Stat.: 131.

Cyclotella Meneghiniana Kützing, 1844.

Brackish water indicator.

Stat.: 193 RR.

Ditylum Brightwelli Grunow, 1881.

In the gatherings from the Amazonas mouth region the specimens were mostly provided with restings spores. These were found also loosely floating in the plankton. One specimen with 4 corners was found, at station 196.

Stat.: 115, 131, 139 R. 140, 159 (many spores), 161, 196 and 213.

Eupodiscus antiguus Cox., 1889. (Plate IV, fig. 12)

One only found $-0.129 \mathrm{~mm} \varnothing$.

Stat.: 193.

Hemiaulus sinensis Gréville, 1865.

Stat.: 115 and 213.

Hemidiscus membranaceus Cleve, 1873.

Stat.: 160.

Hemidiscus ovalis Lohman, 1938.

Meister - Asien. Coscinodiscus planetophorus, plate XII, fig. 86, 87, 1928.

Müller-Melchers, p. 117, plate II, fig. 4, 1955.

Hyalodiscus laevis Ehrenberg, 1845.

Stat.: 196 RR.

Lauderia borealis Gran., 1900.

Stat.: 115, 193 and 196.

Lithodesmium undulatus Ehrenberg, 1840.

Stat.: 213.

Nitzschia coarctata Grunow var. oceanica Frenguelli, 1928.

Oceano Atlántico, p. 512, lam. I, fig. 13.

Stat.: 196. 
Nitzschia pungens var. atlantica Cleve, 1897 (Plate VI, fig. 18, 19),

Treat. Phytopl. Atl. Tribut., p. 24, pl. 2, fig. 24.

Valves linear lanceolate, acute. United in stiff chains by the overlapping tips of the cells (Cupp, 1943).

Length $0.071-0.162 \mathrm{~mm}$ long $\times 0.0023-0.0048$ broad Keal puncta obsolete, of the same number as the striae: 11 to 16 (usually 13/14). Closely related to Nitzschia seriata but cells are more pointed, valves narrower and mostly with greater overlapping of cells endings. Striae visible in water, not visible in $N$. delicata. Stat.: 115, 131, 140, 159 and 161.

Nitzschia seriata Cleve, 1883.

Stat.: 193 and 212.

Pleurosigma affine Grunow, 1880.

Stat.: 193 and $212 \mathrm{~S}$.

Pleurosigma brasiliana, n. sp.

0.457 to $0.516 \times 0.052$

Valve lanceolate, elongated with sharply acute ends. Median line central, slightly sigmoid, the ends are turned in contrary directions. Axial area small, nodule oblong. Structure in transverse and oblique lines, seen with utmost difficulty. Oblique lines crossing at about $60^{\circ}$. Both striations 30 to 32 lines in $0.01 \mathrm{~mm}$ (counted by photography). Same structure in the middle part as in the endings.

Marine pelagic.

Stat.: 193.

Also found at Cananéia. Ilha do Bom Abrigo. $25^{\circ} 07^{\prime} 4^{\prime \prime} \mathrm{S}-47^{\circ} 51^{\prime} 5^{\prime \prime}$ W. Andrade \& Teixeira.

Atlantida (Uruguay) MM.

The nearest form is, as far as bibliography is available - Frenguelli Pl. atlanticus : Diatomeas del Oceano Atlantico 1928. Anales Museo Hist. Nat. B. Rivadavia Buenos Aires.

$0.348 \times 0.042 \mathrm{~mm}$ with 26 transverse stria. Oblique not visible. P. T. Cleve in Nav. Diat. I, p. 41.

Pleurosigma Stuxbergii Cl. et Gr. is somewhat near to this form but the striation is different and the lenght is less, also the central nodule is rhomboid.

Pleurosigma naviculaceum Brébisson, 1854.

Stat.: $193 \mathrm{R}$.

Rhizosolenia alata var. gracillima Grunow, 1881.

Stat.: 115, 145, and 159.

Rhizosolenia alata var. indica Ostenfeld, 1901.

Sтат.: 193, 196 and 213. 
Rhizosolenia Bergonii H. Peragallo, 1892.

Warm water indicator. Subtropical, tropical. Stat.: 212 and 213.

Rhizosolenia calcar avis M. Schultze, 1858.

Oceanic. Marine.

Stat.: 193 and 212.

Rhizosolenia hyalina Ostenfeld, 1901.

Rode hav og Aden bugten., p. 160-61, fig. 11, 1901.

Hustedt, A. S. A., pl. 319, fig. 11-13, Japan Binnenmeer Akashi, 1920.

Skwortzov, Korean Straight, Sea of Japan, Northern Tsushima Island, Sept. 13, $1925,1931$.

Allen \& Cupp, Java, as Rhizosolenia Clevei, p. 128, fig. 34, 1935.

Gaarder, Michael Sars, North Atlantic Deep Sea Exped., 1910. 1951.

Müller-Melchers, 1957, found, not rare, in small quantities off the Ilha do Bom Abrigo, Cananéia, Brazil, in oceanic waters.

Gaarder found Rhizosolenia hyalina in the Central Atlantic on the border of the Sargasso Sea at the following stations:

St. $6322.6-36^{\circ} 51^{\prime} \mathrm{N}-43^{\circ} 58^{\prime} \mathrm{W}$

St. $6424.6-34^{\circ} 44^{\prime} \mathrm{N}-47^{\circ} 52^{\prime} \mathrm{W}$

To my knowledge this is the first mention of this diatom in the Atlantic, till then only known from southern Asia and Japan.

Very transparent. Areolation could not be seen.

Stat.: 193 (very rare specimens).

Rhizosolenia imbricata var. Shrubsolei (Cleve Schröder, 1906.

Stat.: 115, 193, 196, 212 and 213.

Rhizosolenia robusta Norman, 1861.

Stat.: 193 R.

Rhizosolenia setigera Brigtwell, 1858, var. daga n. var. (Plate VI, fig. 20.

This new variety is well known all along the Brazilian coast, I did not insist in my paper "Las Diatomeas del plancton marino de las Costas del Brasil" but the amount of plankton gatherings that were examined during my stay at São Paulo showed that this Rhizosolenia was constant in built, showing a very heavy, daggerlike, spine withourt the long hair ending. It is by all means a variety or type of its surroundings.

Stat.: 115, 125, 131, 145, 159 and 193.

Rhizosolenia Stolterfothii H. Peragallo, 1888.

Bull. Hist. Nat. Toulouse, vol. 2, p. 82, pl. 6, fig. 44, 1888.

Found also at Cananéia in 1957. I found some of this diatom in marine gatherings, but it seems to be scarce on the Brazilian coast. Uruguay, one single specimen was found only. Not known on the Argentine coast. Stat.: 212. 
Skeletonema costatum (Gréville) Grunow, 1866.

Stat.: 115, 131, 140, 193, 212 and 213.

Stephanopyxis Palmerianum (Gréville) Grunow, 1884.

Tropical and subtropical warm water indicator.

Stat.: 193, 212 and 213.

Surirella fastuosa Ehrenberg, 1852 (Plate IV, fig. 15)

Stat.: $196 \mathrm{R}$ and $212 \mathrm{R}$.

Surirella rorata Frenguelli, 1935.

Brackish water.

Stat.: 193.

Thalassionema nitzschioides Grunow, 1881.

Sтат.: 115 and 193.

Thalassiosira decipiens (Grunow) Jorgensen, 1905.

Stat.: 193 and 213.

Thalassiosira subtilis (Ostenfeld) Gran., 1900 (Plate V, fig. 16)

Ostenfeld, Lagttag. Overfl. Temp. Salth. Plankt. (Podosira subtilis), 1900.

Gran, Nyt Mag. Naturvid., vol. 38, pl. 2, p. 117, 1900.

Oceanic temperate species. Embedded in irregular gelatinous masses. Stat.: 140 and 145.

Thalassiothrix Frauenfeldii Grunow, 1880.

Stat.: 115, 131, 139, 140, 145 and 161.

Thalassiothrix longissima Cleve and Grunow, 1880.

Aret. Diat. Kg. Sv., Vet. Akad. Hölg., vol. 17, n. ${ }^{\circ}$ 2, p. 108.

Stat.: 196, 212 and 213.

Thalassiothrix mediterranea Pavilland 1916 var. pacifica Cupp, 1943.

Cupp, Marine Plankton Dist. West. Coast North America, p. 185, fig. 136, 1943.

Differs from the type mainly by the coarser striation $-16-19$ in $0.10 \mathrm{~mm}$ in the variety; $21-24$ in $0.10 \mathrm{~mm}$ in the type.

Stat.: 212.

Trachyneis (Alloioneis) antillarum Cleve, 1894 (Plate V, fig. 17).

Alloineis antillarum, Cleve, West Ind. Diat. p. 8, pl. II, fig. 11, 1878.

Scoliopleura antillarum, Wolle Diat. N. Amer., XLI, fig. 12, 1894.

Trachyneis antillarum Cleve, Syn. Nav. Diat. I, p. 193, 1894.

Navicula antillarum Mann, Albatross, p. 336, 1907.

Trachyneis antillarum Subrahmanyan, Madras, p. 183, f. 409, 1946.

Virgin Islands, St. Bartholomew, Cleve. Gulf of Mexico, Grunow. Rio Grande do Sul (Barra), Cuba, Müller-Melchers. Lower California, Mann. 
Marine brackish, bottom samples, incidently in plankton.

Stat.: 193.

Triceratiun favus Ehrenberg, 1839.

Stat.: 193 (Brackish).

Triceratium patagonicum A. Schmidt, 1895 (Plate III, fig. 10 ).

A Schmidt Atlas, plate 82, fig. 8 .

Stat.: 212.

\section{R E S U M O}

Estuda-se, no presente trabalho, o material coletado ao longo da costa brasileira pelo navio "Toko-Maru".

As coletas podem ser distribuídas em dois grupos tais como: quatro amostras provenientes do sul e as restantes 14 da circumvizinhança da desembocadura do Rio Amazonas, abaixo e acima do Equador.

Esses dois grupos são bem distintos. As quatro amostras do sul apresentam muita semelhança com o material das províncias riograndense e uruguaia. Nelas prevalecem formas discoides de Actinocyclus e Coscinodiscus.

O autor encontrou Chaetoceros Okamurai Ikari, nova para a América do Sul, o mesmo acontecendo com Nitzschia pungens var. atlantica Cleve. Em relação a Rhizosolenia hyalina Ostenfeld, acredita o autor ser esta a primeira vez em r'ı essa diatomácea do sul da Asia é referida para o Atlântico.

Descreve o autor uma espécie nova: Actinocyclus brasiliensis e uma nova variedade: Rhizosolenia setigera Brightwell var. daga.

$O$ exame das amostras permitiu concluir que o material das vizinhanças do Amazônas é pobre em formas, consistindo principalmente de Coscinodiscus concinnus W. Smith e, em menor quantidade, de C. oculus iridis Ehrenberg. Essas duas diatomáceas acham-se acompanhadas por Nitzschia pungens var. atlantica Cleve, não raro confundida com $N$. delicatissima Cleve.

\section{B I B L I O G R A F A}

Allen, W. E. \& Cupp, E. E.

1935. Plankton diatoms of the Java Sea. Ann. Jard. Bot. de Buitenzorg, vol. XLIV, part 2, p. 101-174.

Brockmann, C.

1928. Diatomeen im mar. Quartaer Hollands. Senkenberg.

BRUN, J.

1891. Espèces nouvelles. Soc. Phys, et Hist. Nat. Genève, vol. XXXI, n. 2. Cleve, P. T.

1878. Diatoms West Ind. Archip. K. Sv. Vet. Ak. Hdlg., vol. 5.

Cleve Euler, A.

1952. Diatomeen von Schweden und Finnland. K. Sv. Vet. Ak. Hdlg., vol. 3, n. 9 .

Cupp, E. F.

1943. Marine plankton diatoms of the West coast of North America. Bull. Scripps Inst. Ocean., vol. 5, n. ${ }^{\circ}$ 1, p. 1-238. 
Frenguelli, J.

1928. Diatomeas del Océano Atlantico frente a Mar del Plata. Ann. Mus. Nac. Hist. Nat., "Bern Rivadavia", vol. 34, p. 497-572. Buenos Aires.

GAARDER, K. R.

1951. Bacillariophyceae from the "Michael Sars" North Atlantic Deep Sea Exp. 1910. Rep. Sci. Res., vol. 2, n. ${ }^{\circ}$ 2, p. 1-36.

Hendey, N. J.

1937. The plankton diatoms of Southern Seas. Discovery Reports, XVI, p. 151-364.

Hustedt, F.

1927. Die Kieselalgen Deutschlands, Osterreichs und der Schweiz mit Berücksichtigung der übrigen Länder Europas sowie der angrenzenden Meeresgebiete. In Rabennhorst, Krypt. Flora 7. Leipzig.

1939. Die Diatomeenflora des Küstengebietes der Nordsee vom Dollard bis zur Elbmündung, Teil 1. Abh. nat. Ver. Bremen, vol. 31, n. 3.

IKARI, J.

1928. On some Chaetoceros of Japan. II. Bot. Magazine, vol. XLII, n. 997. Tokyo.

Lohman, K. E.

1938. Pliocene diatoms from the Kettleman Hills. U. S. Geol. Surv., Prof. Paper, 189-C, p. 81-94, pl. 20-23.

1941. Geology and biology of North Atlantic Deep-Sea Cores... Part 3, Diatomaceae. U. S. Geol. Surv., Prof. Paper, 196-B, p. 55-86, pl. 12-17.

Mann, A.

1907. Report on the diatoms of the "Albatross" voyages in the Pacific Ocean, 1888-1904. Contrib. U. S. Nat. Herb., vol. 10, part 5, p. 221-419.

1937. Diatoms. Australasian Antaretic Exp., 1911-14, vol. 1, part 1. Sydney.

Meister, F.

1932. Kieselalgen aus Asien.

Müller-Melchers, F. C.

1953. New and little known diatoms from Uruguay and the South Atlantic coast. Com. Bot., Mus. Hist. Nat. Montevideo, vol. 2, n. ${ }^{\circ} 30,11$ p. pls. 1-7.

1955. Las diatomaceas del plancton marino de las costas del Brasil. Bol. Inst. Ocean., vol. 6, n. ${ }^{\circ}$ S $1 / 2$, p. 93-142. São Paulo.

Peragallo, H. \& M.

1897-1908. Diatomés marines de France et des districts maritimes voisins: atlas. Paris, M. J. Tempére.

Rattray, J.

1889. A revision of the genus Coscinodiscus and some allied genera. Proc. Royal Soc. Edinburgh, vol. 16, p. 482.

1890. A revision of the genus Actinocyclus.

SchMid, A.

1874. Atlas der Diatomaceen-kunde. Leipzig, Reisland.

Skvortzow, B. H.

1931. Pelagic diatoms of Korean Strait Philip. Jour. Sci., vol. 46, n. ${ }^{\circ} 1$. 


\section{$-126-$}

\section{P LA T E I}

1 a Actinocyclus brasiliensis n. sp. $0.086 \varnothing$

b Actinocyclus brasiliensis higher focus.

2 Actinoptychus areolatus Ehrenberg $0.0855 \varnothing$

3 Actinoptychus areolatus Ehrenberg $0.092 \varnothing$

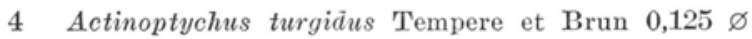




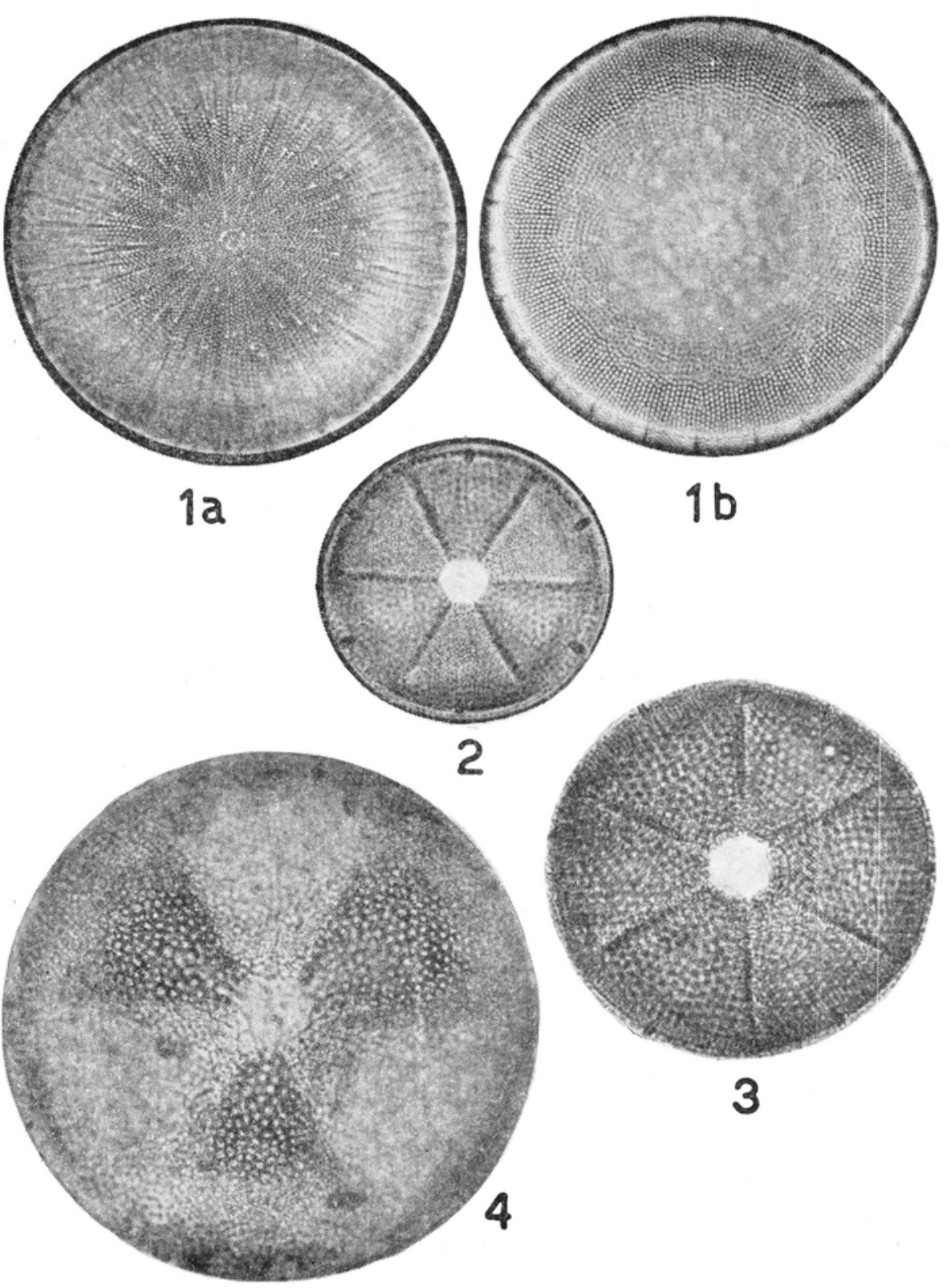




\section{P L A T E I I}

5 Actinocyclus senarius Ehrenberg $0.166 \varnothing$

6 Coscinodiscus Jonesianus var. aculeata Meister

7 Coscinodiscus Kurzii Grunow ex A. Schmidt Atlas

8 Coscinodiscus Kurzii $0.123 \varnothing$ from "Toko" Maru 
Müller-Melchers, F. C. - Plankton Diatoms...

PLATE II
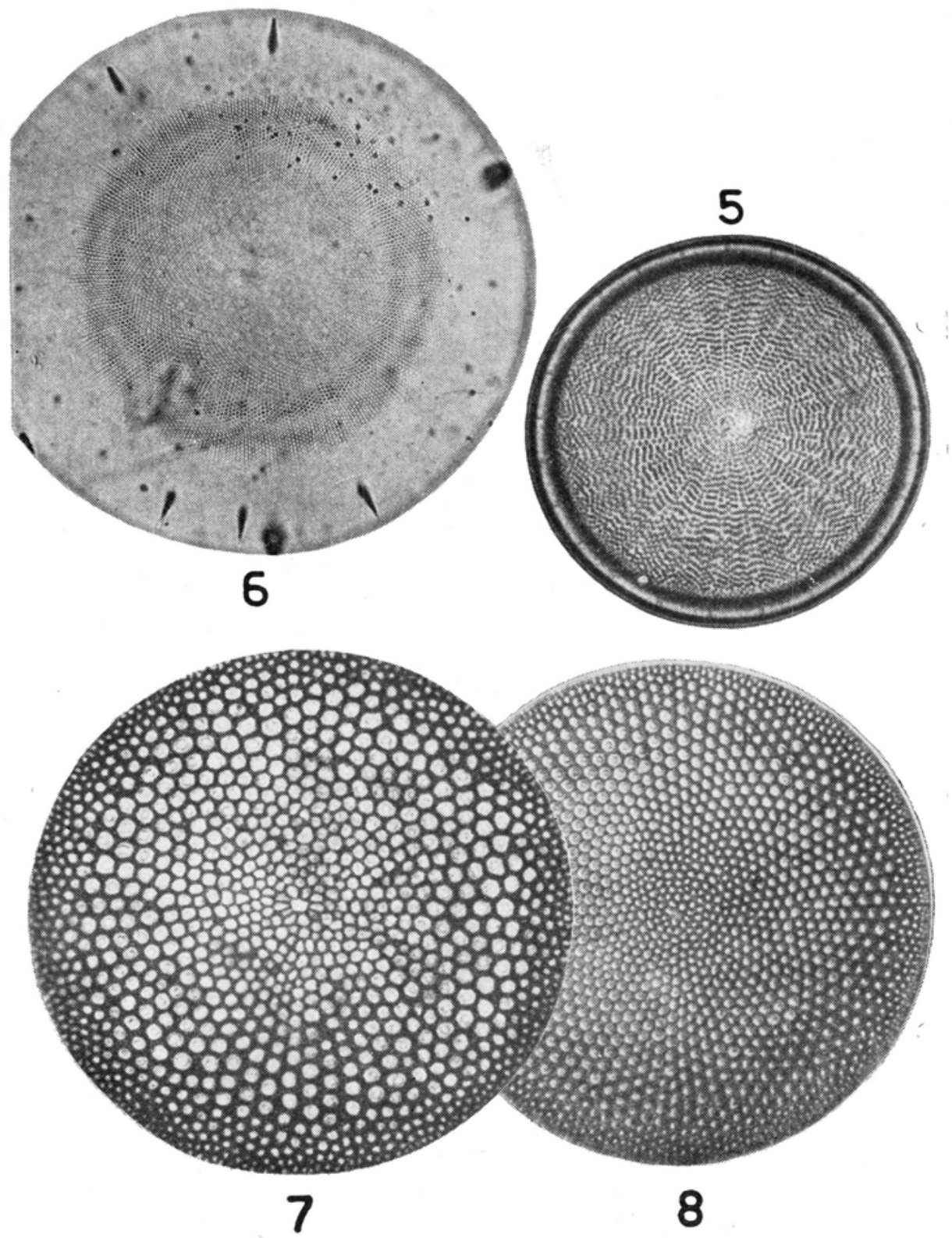
$-130-$

P L A T E I I I

$9 \quad$ Asteromphalus Hookerii Ehrenberg $0.04615 \varnothing$

10 Triceratium patadonicum A. Schmidt 0.130 one side.

11 Chaetoceros pseudocurrisetus Mangin $0.018 \varnothing$ with resting spores. 
Müller-Melchers, F. C. - Plankton Diatoms...
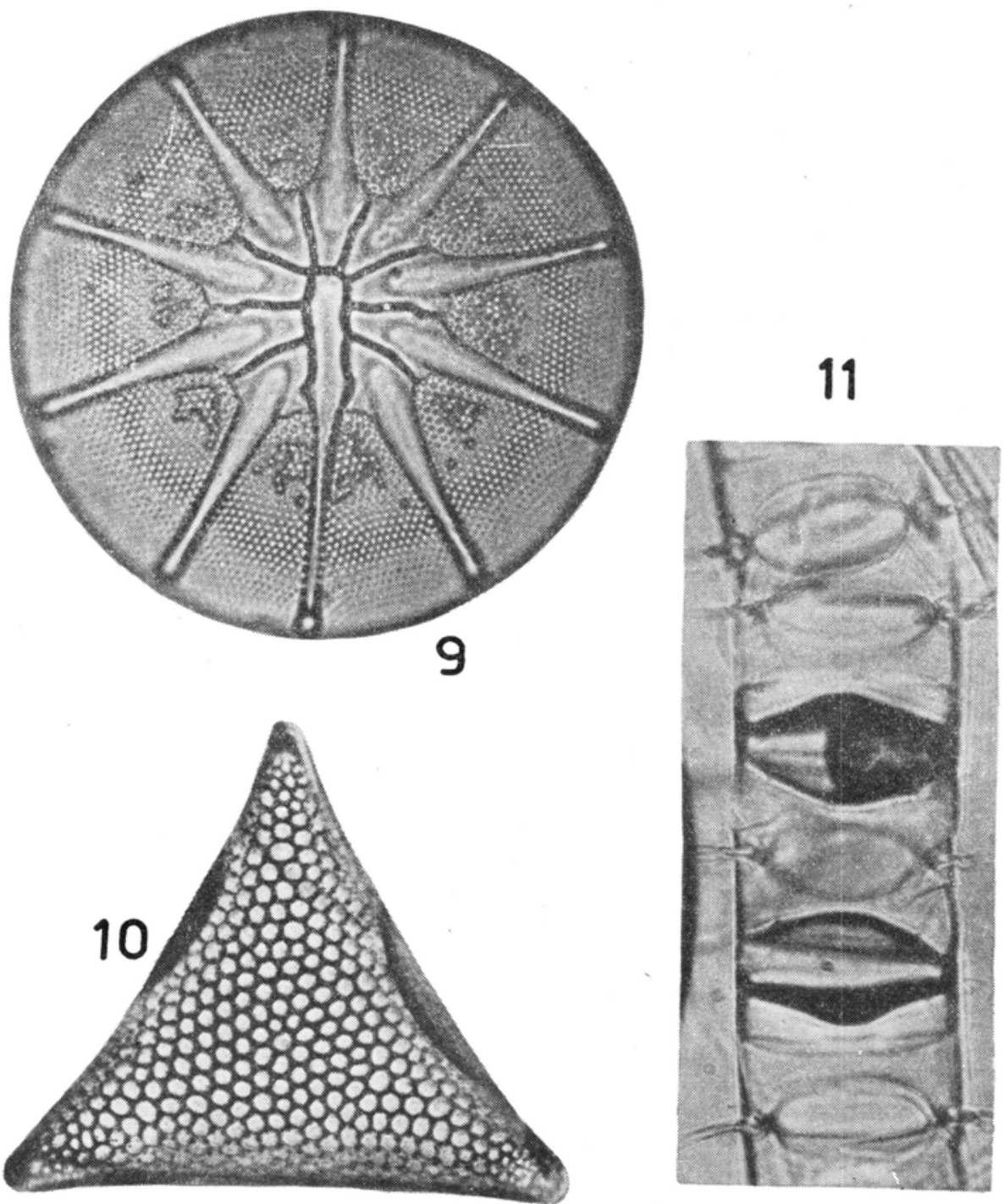
$-132-$

\section{P L A T E I V}

12 Eupodiscus antiquus Cox $0.092 \varnothing$

13 Chaetoceros lorenzianas Grunow resting spores.

14 Surirella rorata Frenguelli $0.165 \times 0.083$

15 Surirella fastuosa Ehrenberg $0.043 \times 0.0285$ 

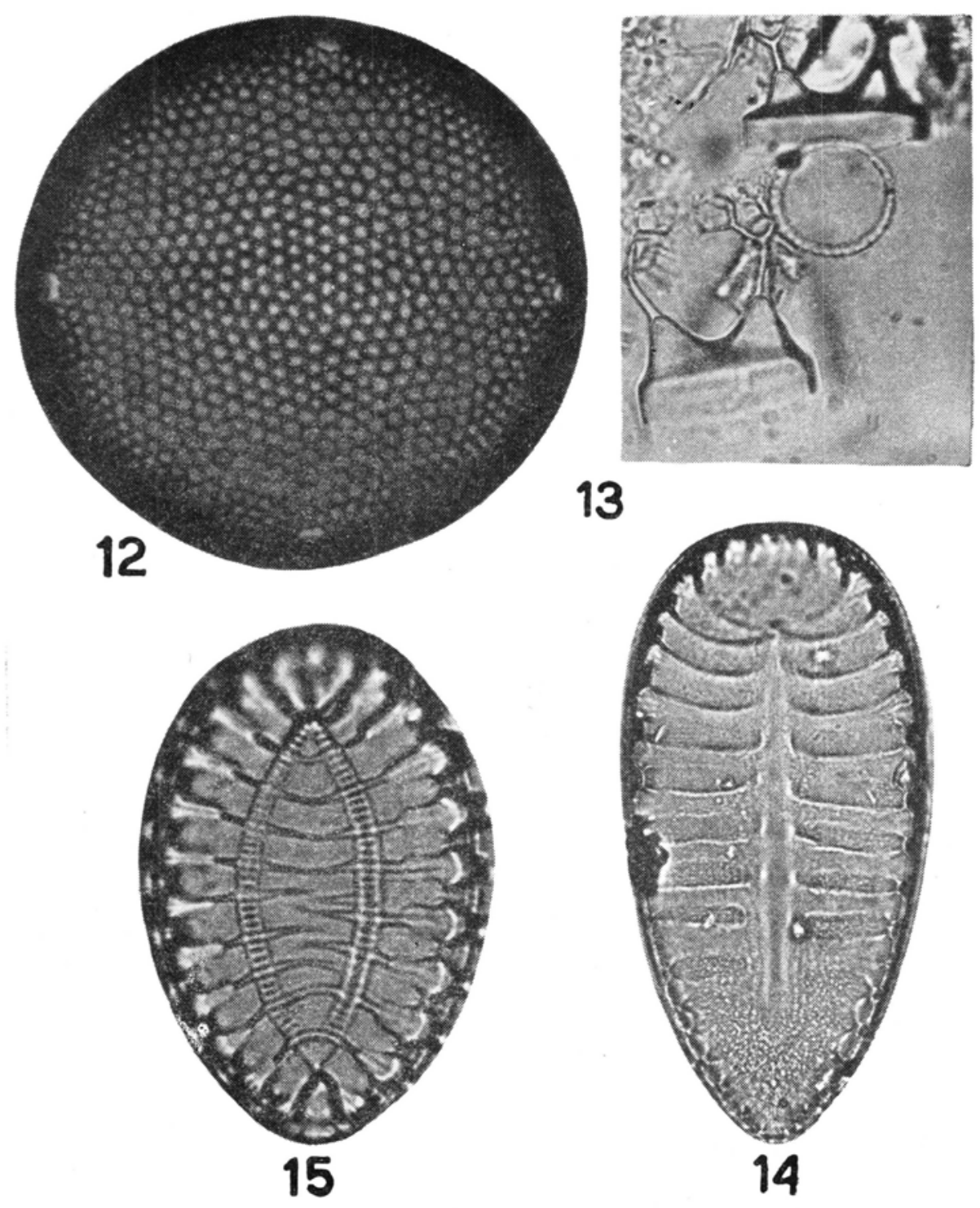

13

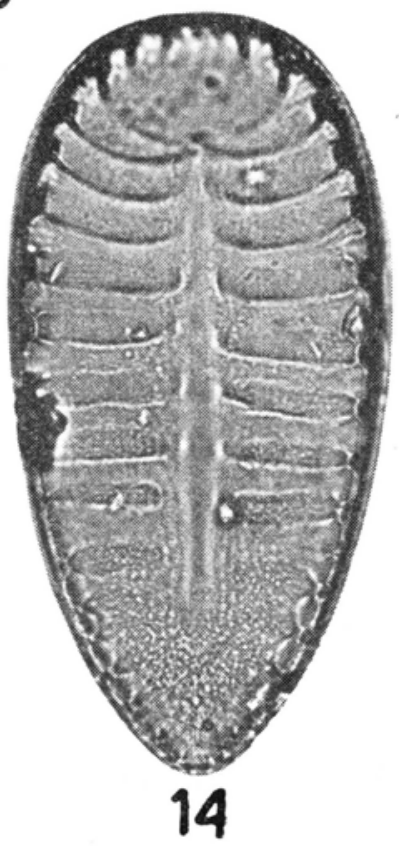


$-134-$

P LATE V

16 Thalassiosira subtilis Ostenfeld $0.024 \varnothing$

17 Trachyneis antillarum Cleve $0.165 \times 0.029$ 


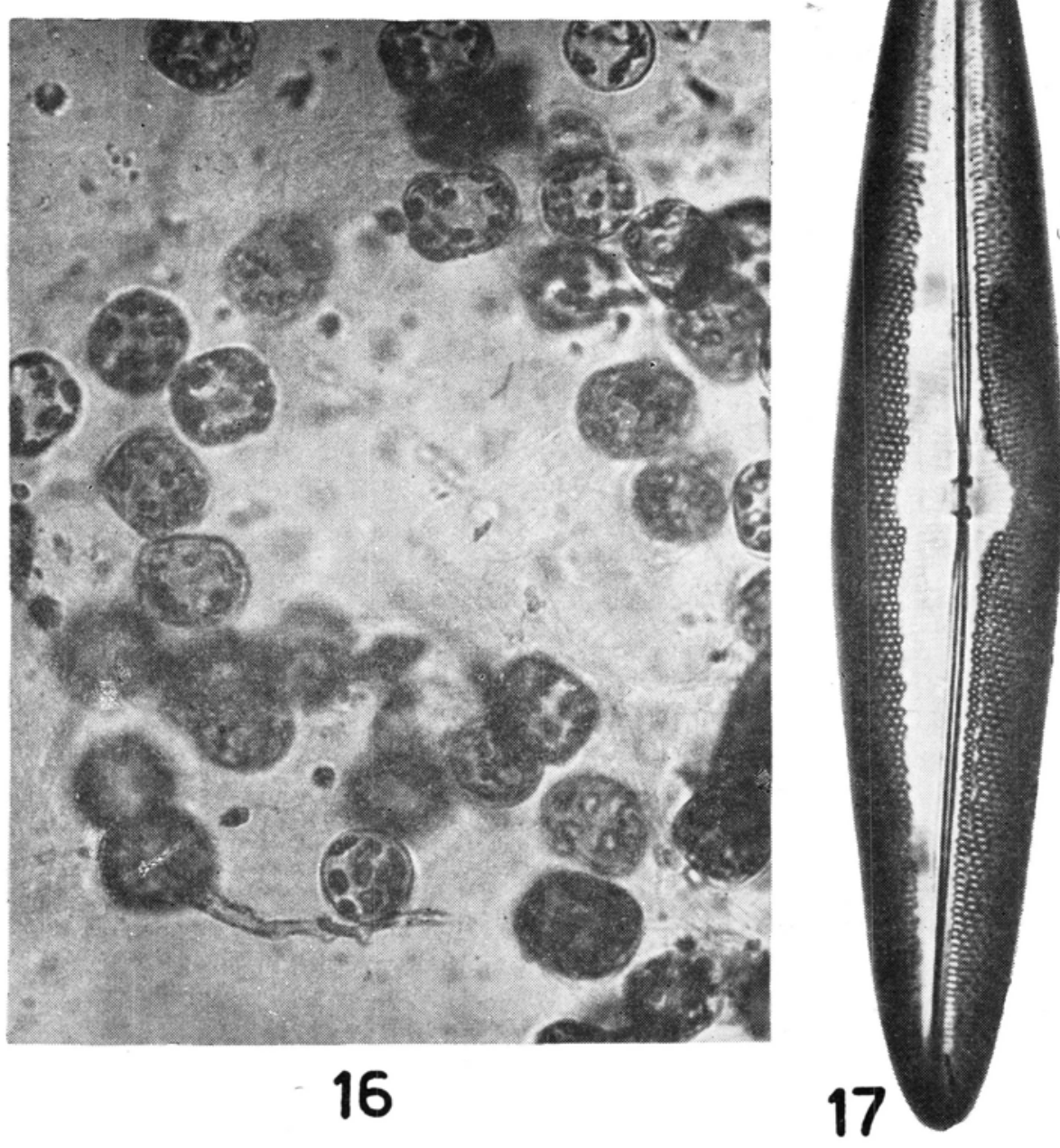


18 Nitzschia pungens var. atlantica Cleve

19 Nitzschia pungens var. atlantica Cleve

20 Rhizosolenia setigera $\mathrm{n}$. var. daga

21 Chaetoceros Okamurai Ikari

22 Corethron pelagicum Brun

23 Pleurosigma brasiliana n. sp

24 Terminal part.

25 Central part 
Müller-Melchers, F. C. - Plankton Diatoms...

PLATE VI

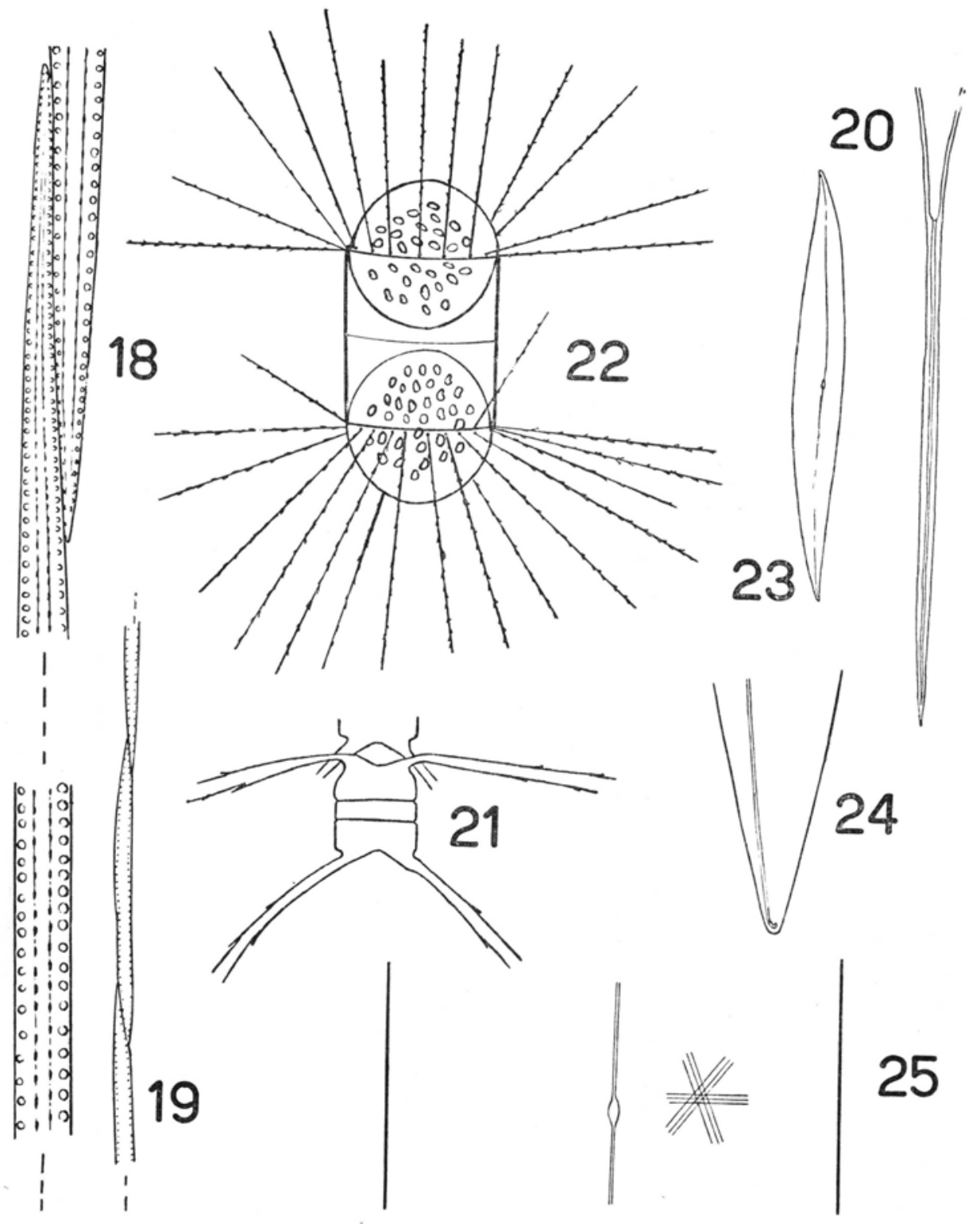




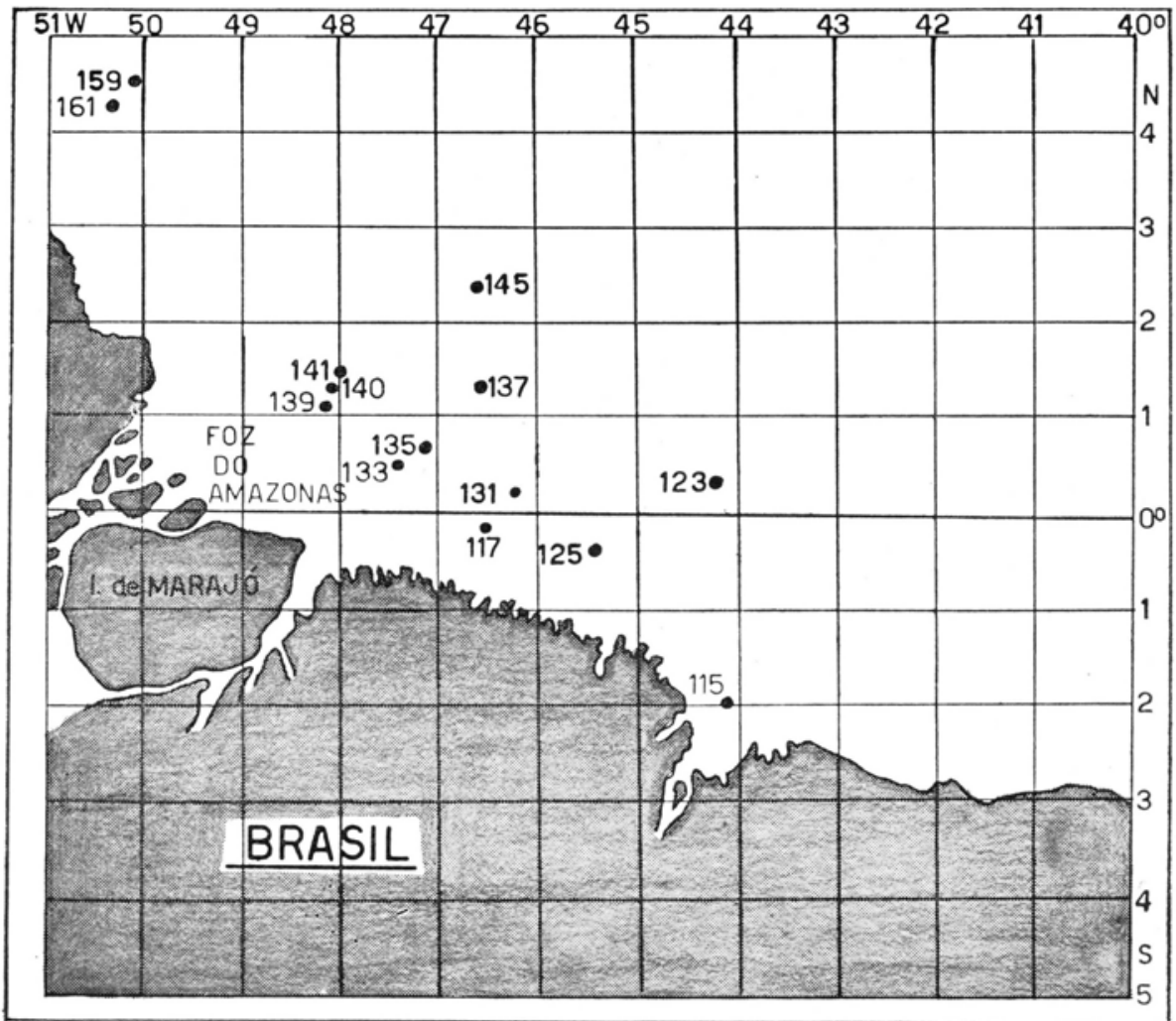

Stations of "Toko-Maru" - 1957 - along the Brazilian coast. 